\title{
Imagined community and governance of Catalonian cultural action abroad: midway between corporatism and social participation
}

\author{
Mariano Martín Zamorano \\ UNIVERSITAT DE BARCELONA \\ martinzamahotmail.com
}

Received: 28/04/2016

Accepted: 26/05/2016

\begin{abstract}
Benedict Anderson (1993) defined nation as "an imagined political community - and imagined as both inherently limited and sovereign", and stressed the importance of cultural roots for the establishment of this national consciousness. Cultural diplomacy, organized by nationstates since the early $20^{\text {th }}$ century and politically structured on the basis of this sovereign and imagined space, sought to extend the influence of countries through the promotion of national culture on the international scenario. This article examines, by contrasting Anderson ideas, the impact of nationalism on the organization of a corporatist structure for the governance of Catalan foreign cultural action between 1980 and 2014.

Keywords: cultural paradiplomacy, Catalonia, governance, nationalism, imagined community
\end{abstract}

Corresponding author: Mariano Martín Zamorano. Universitat de Barcelona. Departament de Teoria Sociològica i Metodologia de les Ciències Socials. Facultat d’Economia i Empresa. C/ Tinent Coronel Valenzuela, 1-11, 08034 Barcelona.

Suggested citation: Zamorano, (2016). Imagined community and governance of Catalonian cultural action abroad: midway between corporatism and social participation. Debats. Journal on Culture, Power and Society, 1. 45-58

\section{INTRODUCTION}

Bendict Anderson $(1993,23)$ defined nation as "an imagined political community — and imagined as both inherently limited and sovereign." From the stance of a critique on materialistic reductionism but, likewise, idealistic primordialism, he stressed the importance of analysing cultural roots if we are to understand the construction process of the many forms of territorial national power that ensued during modernity. As of the nineteenth century, this social construction of political nationalism, linked to the official cultural heritage, has been mirrored by the systematic political actions undertaken abroad by national associations. The first private associations abroad, integrated by liberal elites and, to a lesser extent, other nationalist sectors mobilized by the workers movement, sought to sustain the colonial power or strengthen their regional networks by spreading their language and national heritage (Paschalidis, 2009). Thus, the evolution of foreign cultural policy is linked with numerous strategies to build international hegemony, founded upon a certain concept of nation.

With respect to Catalonia, since the democratic transition, the internationalization of culture and transnational actions aimed at disseminating the political demands of the region, were based on a nationalist perspective. The latter aimed to recover the progress made during the Second Republic in these issues, the otherness of this territory and its society as compared to the other cultures of Spain, and its association with other regions and countries of central and northern Europe. On the basis of this discourse, an area of cultural action abroad 
grew with relative autonomy, both with respect to other areas in the regional administration and in relation to the cultural diplomacy of the State (Petit Bozzo, 2010). In this respect, with its institutionalization in the nineties, this policy incorporated into its governance numerous associations and institutions devoted to projecting Catalan culture within a national context, which had emerged within the context of political dispute in the years following Franco's death. For example, this was the case of several social organizations in the sector that the Consorci Català per a la Promoció Exterior de la Cultura (Catalan Consortium for the External Promotion of Culture, COPEC) took on board after its creation in 1991.

Later, however, with the foundation of the l'Institut Català de les Indústries Culturals (Catalan Institute of Cultural Industries, ICIC) and the Institut Ramon Llull (IRL) in 2000 and 2001 respectively, this aggregation process of actors playing in the international projection of national culture underwent numerous changes in corporatist mechanisms. This renewal of cultural paradiplomacy promoted diverse tensions between the public and private members of the socio-institutional framework. These were primarily related to the new role that the Generalidad (Catalan Government) took in this activity and its subsequent protodiplomatic turn ${ }^{\mathbf{1}}$.

There are manifold reasons for this general evolution of Catalan cultural foreign policy, but they have a clear link with the various political forms adopted by nationalism in the region. The "political power" of nationalism and the force of the sovereign state as a project embarked upon the "freedom of the nation" (Anderson, 1993, 25) have had a clear impact on the socio-political organization of Catalan cultural paradiplomacy; however, this phenomenon has not been properly analysed. Indeed, within a predominantly statist theoretical framework, focused on military and economic disputes, cultural diplomacy has been neglected or considered as a trivial area of diplomacy (Bélanger, 1994, 423, Mark, 2008: 5). Moreover,

1 Duchacek (1990) has defined paradiplomacy as the use of foreign policy by the sub-states with the aim of obtaining independence. the subordinate nature of sub-state elements and dynamics disapproved of by national models in the arena of cultural policies (Johannisson, 2010; Schuster, 2002) contribute to the fact that currently cultural paradiplomacies still constitute a scarcely studied and loosely established phenomenon. In this respect, the case of Catalonia calls into question the functionalist theories explaining the construct of national power, which assume the nation to be a capital of political legitimation of the concentration of state power and an instrument of domination of the political and economic elites, as well as neorealist theories, which relegate the power of ideational and agential elements in foreign policy to the background (Vilanova, 2007).

Based on an approach proposed by Anderson regarding the cultural nation, and on fieldwork conducted between 2012 and 2014, this article will examine the incidence of nationalism in structuring a field of corporatist governance, which characterized the foreign cultural action of Catalonia between 1980 and 2014.

\section{FOREIGN CULTURAL POLICY AND NATIONALISM}

The term 'cultural diplomacy', institutionalized in the early twentieth century and whose most representative historical exponents are the Alliance Française (1923) and the Goethe Institute (1921), currently has a host of definitions. According to Milton Cummings, cultural diplomacy is about "the exchange of ideas, information, art and other aspects of culture among nations and their peoples in order to foster mutual understanding." (Cummings, 2003, 1).

By contrast, Arndt has distinguished between 'cultural diplomacy' and 'international cultural relations': "cultural diplomacy can only be said to take place when formal diplomats, serving national governments, try to shape and channel this natural flow to advance [elusive] national interests", which are difficult to define (Arndt, $2009,31)$. As the authors suggest, it is a range of actions for the external dissemination of culture, arts or the symbolic heritage of a social group, involving systematic government intervention. 
Currently, cultural diplomacy is characterized by the proliferation of actors involved at different scales and levels, as in the case of cultural paradiplomacies, i.e., those foreign cultural activities undertaken by sub-state governments (Mesado i Jardí, 2008; Bélanger, 1997). Besides, given the importance of the cultural sphere in today's globalized world (Morató 2007), it ranks as one of the fundamental instruments of national construction and promotion on the international stage. Likewise, reflecting its complex relationship with domestic policy, the importance of strengthening national systems of culture has been highlighted as a requisite for apposite external projection (Saul, 1994). This area of action, subject to the propositional dynamics of governments, involves governments of a nation, as well as their entrepreneurs, artists, migrants, etc. However, this exchange is relatively defined, in each case, by official definitions of culture and of nation, operationalized by governmental institutions and agents.

But what role does nationalism play in shaping foreign cultural policy? Beyond the various theses posed by functionalism $^{2}$ and idealism ${ }^{3}$ to explain nationalism, several authors have focused their attention on analysing its socio-historical forms of construction. They have

2 Within this theoretical framework, the emergence of modern nationalism relates to the emergence of an industrial society in the eighteenth century, which, unlike agrarian societies, had to be politically centralized in order to function. Thus, the public education system - and subsequently the cultural one - favoured the systematization of the relationship between the productive industrial forces and the workforce, considering the spread of the national ideal as a mechanism justifying the concentration and organization of political and economic power (Gellner 1997, 18).

3 In contrast, nationalist theory from the perspective of the idealism, Elie Kedourie states the existence of what he calls nationalist doctrine. It "holds that humanity is naturally divided into nations, that nations are known by certain characteristics that can be ascertained, and that the only legitimate type of government is a national self-government." (Kedourie, 1998 1). Within the context of this thesis, as of the nineteenth century the state instated a series of cultural elements and common interests that had existed in various forms since ancient Rome. Therefore, the principle of all sovereignty resides in the nation itself and, all this which is essentially based on a common culture, is the foundation that supports the whole. The individual cannot be understood, therefore, outside his/her national context or outside the entity he/ she naturally integrates (Kedourie, 1998, 33). highlighted the importance of social movements in the accumulation of power and national symbols (Hobsbawm, 1991, 19; Hroch, 1994, 47; Anderson, 1993, 193). In this respect, according to Eric Hobsbawm: "Nationalism comes before nations. Nations do not make states and nationalisms but the other way around."(Hobsbawm, 1991, 18). In a proximate stance, for Anderson the extension of literacy together with the advent of the printing press and the construction of Republican power, were three facets of modernity that fostered national consciousness (Anderson, 1993 65).

But Anderson also noted the capacity demonstrated by the ruling elites, throughout modern history, to promote and provide certain directionality to this political power, following various geopolitical strategies (Anderson, 1993). In this respect, the author carefully analyses the importance of fostering an official narrative regarding the nation's colonial expansion processes or, to the contrary, national defence against external agents (Anderson 1993, 147).

Hall said that nationalism acquired new manifestations in the twentieth century, from being a support element of national sovereignty (raison d'état) to also become as a factor of national self-determination. In this respect, several authors have explained the uses of foreign cultural action undertaken by substate nations, and the importance of nationalism to explain the birth, legitimisation and advancement of cultural paradiplomacy (Lecours and Moreno 2003, p. 3; Michelmann, 2010). Here, cultural action abroad is presented as an instrument shaping the imagined nation to which Anderson refers, while, at the same time, it is an activity "shaped" by its political and economic bases. Our analysis of the governance of cultural paradiplomacy of Catalonia reveals a constant theoretical and factual tension between cultural nationalism, which takes various socio-political forms, and the political manipulation and institutionalization of national identities. By the latter, we refer to various forms of nationalism "from above"; the advance of government control dominating multiple areas operating in legitimisation, defence and normalization of the constituent elements of the cultural nations. 


\section{GOVERNANCE AND FOREIGN CULTURAL POLICY}

Since the nineties, traditional models of government in cultural diplomacy, which are centralized and subsumed to the strategy of foreign policy, have given rise to new patterns of governance. This implementation model of public policy and of theoretical analysis emerged from the crisis of the Weberian model of government, of a vertical kind and focused on applying the norm (Peters and Savoie, 1995, 389). The same proposes the existence of two interrelated processes of governance in public management: the essentially hierarchical and those structured on the basis of the continuous opening of numerous institutional areas favouring social intervention. However, while the bottom-up governance model was assimilated, in some cases, to greater democratic quality of the Liberal State, due to community intervention in public policy, Peters (1995) has pointed out some drawbacks of this reduction: among other derivatives, this recognition by the State of the shifting social reality could encourage excessive compartmentalization of government bodies, the inefficiency of government action and also the ambiguity of the public regarding the Law (Peters, 1995).

Within the study of contemporary cultural diplomacy, we should consider how the complex process of structuring government expresses the balance between political representation (respecting the principles of equality and legal rules) and its openness to social participation. In this respect, governance in current cultural action abroad also exhibits various corporatist trends that limit community participation. Corporatism has been characterized as a model of government with: a) a strong and leading State, b) with certain restrictions on the freedom and activities of interest groups, and c) the incorporation of these interest groups within and as part of the state system, responsible for representing the interests of its members and for helping the state to manage and carry out public policy (Wiardi, 1996 8). As Wiardi points out (1996: 15) this governance model has been part of various political regimes, ranging from liberal to totalitarian, in which the social groups involved may have a relationship with the State ranging from absolute control over part of it, to contractualism.
Our approach to cultural diplomacy, based on Anderson's analysis of nationalism seeks to clarify the processes and mechanisms of articulation of the same nationally/socially, in as much as certain relationships of co-operation and conflict are established between the representative and the represented. For Villanueva, to represent culture abroad means to concentrate on how nations act in representing themselves abroad, operating to promote the interests of those who belong to the national culture of the country (Villanueva, 2007, 24). This process of building policy is based on different dynamics that include the acts of diplomatic agents (Arndt, 2005) or the strategic agenda of producing this "cultural cutback abroad" undertaken by governmental management. From the historical standpoint, one may notice a general trend towards centralization, autonomization and expansion of the area, and then in the seventies, towards the inauguration of mechanisms bestowing a greater pluralism and capacity for sociopolitical interaction. However, on the other hand, there has been the emergence of a corporatist and privatist dynamic, which means that this representation has been constituted on the basis of geopolitical and economic precepts that form part of the foreign agenda, through various public-private alliances of elites (Villanueva, 2007, 65).

In this respect, cultural representation through foreign policy has particular mechanisms related to social participation processes. As Villanueva indicated, entering the dimension of cultural diplomacy agencies, while the bottom-up structure has been the reference of the idealistic trend in international relations, the topdown one (or diplomacy of elites) has been subsumed in concepts of national interest and acted on corporatively in accordance with its definition (Villanueva, 2007, 46). These modes of relationships between regional sociopolitical processes and cultural diplomacy have been highlighted in different characteristics of the policy. Mellisen $(2005,13)$ refers to public diplomacy in terms of the reference to domestic policy in two ways: the local intervention of citizens in the formulation of foreign policy (participatory approach) or the explanation of diplomacy and the objectives of foreign policy to the local public (explanatory approach). In this regard, 
note has also been made of the importance that foreign policy plays the role of "explaining the world" to the citizens of origin (Sharp, 1999). It has also been noted that cultural diplomacy can transform domestic policy to "incite the compliance with our own national image abroad and strengthen the pride in achievements of a country" (Higham, 2007, 139). By contrast, it has also been warned that cultural action abroad can act as a tool for handling domestic policy and disputes, such as in the case of advanced protodiplomacy in Quebec (Mark, 2008, 71; Bélanger, 1994). In short, according to these different perspectives, cultural diplomacy would play the role of channelling the various local interests, explaining their modes of intervention and foreign response to the same, and fostering social internal cohesion, thereby becoming an instrument of socially constructed sovereignty.

\section{INSTITUTIONAL EVOLUTION OF CATALAN CULTURAL PARADIPLOMACY}

The first stage of Catalan cultural paradiplomacy spanned the period beginning with the first term of the CiU (Convergència i Unió) government in 1980, until 1987, when it created the Subdirecció de Relacions Exteriors i de Protocol (Office of External Relations and Protocol). This first period coincides with the phase of Spanish cultural policy that Bouzada (2007, p. 305) defines as the phase of "construction of identity". In the Catalan case, this was framed within the context of the reorganization of the cultural governmental structure which involved, among other things, transference of civil servants and equipment from the State to the regional administration. At that time, the conservative $\mathrm{CiU}$ government was promoting cultural action abroad, mainly targeting Europe and Latin America, consisting of isolated and uncoordinated actions, with predominantly patrimonial features from in terms of their sociocultural proposal. It was mainly a public cultural paradiplomacy, i.e., aimed at approximating relations with social organizations outside Catalonia $^{\mathbf{4}}$ (Departament de Cultura, 1983, p. 14),

4 For example, with the creation of the Servei Permanent de Casals Catalans in 1980 which in many cases had been mobilized in resistance to Franco's dictatorship.

As of 1987, Jordi Pujol's government began to develop a new policy of cultural paradiplomacy, a trend which grew in the early nineties. The action outside the Catalan administration was to be driven by Spain's integration in the European Union (Delgado Gómez-Escalonilla and Figueroa, 2008, 12), which gave rise to different uses of this "window of opportunity" to promote Catalonia on the European map (Gasoliba, 1987, 48). Moreover, the prominent urban, social and economic transformations that occurred after the election of Barcelona as the venue for the 1992 Olympic Games, favoured the implementation of new and more effective forms of sub-state projection abroad. Thus, greater stability and potential of the political-institutional scenario granted cultural paradiplomacy, now bestowed with "mid- and long-term design and planning of action abroad", with a strategic base for growth (Villalonga, 1992, p. 213). Then we were to witness the establishment of new public agencies devoted to this policy. One of these was the Consorci Català per a la Promoció Exterior de la Cultura (Catalan Consortium for the External Promotion of Culture, COPEC), set up in in 1991, which exclusively tackled this task, focusing to a great extent on the management and international promotion of culture for the Catalonian government. The targets of this policy were extended, with priorities being "Europe, the United States, Japan and Latin America." (García and Segura, 1995, p. 44).

As of 2000, in its final stage Catalan cultural paradiplomacy received a strong boost. The new strategy was aimed at modernizing its projection abroad and, in this context, fostering the "Catalonian brand", somewhat overshadowed since the nineties due to the branding of Barcelona. Then they created different areas of management, designed from a rationale that sought to meet the diverse challenges presented by globalization. Cultural paradiplomacy was to be equipped with new institutions and, simultaneously, the scope of international action of the Department of Culture was to be extended. In this context, the Institut Català de les Indústries 
Culturals (Catalan Institute of Cultural Industries, 2000) and the Institut Ramon Llull (2001) were to make an appearance, providing Catalonia with the capacity for cultural action abroad difficult to compare with that of other sub-state entities. Thus, there was an increase in the use of cultural industries and digital platforms as instruments of international cultural promotion. This line of action would intensify with the change in regional government in 2003. At this point, the new left-wing administration ${ }^{5}$ would make progress in structuring foreign policy by establishing relationships, organizations and offices in several countries ${ }^{6}$. This renewed structure and significant legal redesign of this area under the new Statute of Autonomy (Estatut d'Autonomia, 2006), helped strengthen Catalonia's international presence, with milestones such as the Frankfurt Book Fair or becoming the capital of the Union in the Mediterranean. (Villarroya Planas, 2010, 11). However, different events, such as the resolution of the Constitutional Court (Tribunal Constitucional, TC) on the Statute of Autonomy of Catalonia (Estatut d'Autonomia de Catalunya) in 2010 and political effects of the economic crisis which had begun two years earlier, supported the reduction and rationalization of the system, as well as the adoption of strategies aimed at achieving greater autonomy in this matter, within the framework of growing parliamentary consensus about holding an opinion poll (Consulta) on independence ${ }^{7}$.

5 We refer to the triumph after 23 years of a coalition government, the so-called Tripartite, with the left-wing parties: Partit dels Socialistes de Catalunya, Ciutadans pel Canvi, Esquerra Republicana de Catalunya and Iniciativa per Catalunya Verds-Esquerra Alternativa.

6 These organizations came to form a network of more than two hundred centres representing this region abroad, in various institutional forms and different strategic sectors.

7 It was entitled "popular consultation, not a referendum, on the political future of Catalonia" and was convened in September 2014 through the adoption by the Catalan Parliament of an Inquiries Act and the subsequent signing of a decree by the President of the Catalan government, calling for it to be held on $9^{\text {th }}$ November 2014. During the same month, it was provisionally suspended by the Tribunal Constitucional (Spanish Constitutional Court, TC).

\section{CORPORATIST GOVERNANCE OF THE CATALAN CULTURAL PARADIPLOMACY}

We should distinguish the aforementioned strategic and sectoral diversification processes of the Catalan cultural foreign policy and the many dynamic forces driving bottom-up intervention, of the development that led to the formation of corporatist governance in this policy. As previously stated, during the seventies organizations joined in this task as part of the process of post-Franco cultural "normalization". Social mobilization around the international promotion of culture, nested within the framework of nationalism, was a political asset influencing regional government organization during the democratic transition. But, in many cases, this bottom up movement was to become subject to a gradual transformation that led to the institutionalization of governance in foreign cultural policy in the nineties. In this context came the renewal of various cohesion and co-operation mechanisms between interest groups and actors involved in this framework, reaffirming its corporatist nature (Wiardi, 1996). Since then, one of specific traits of the Catalan system of cultural paradiplomacy is the existence of different publicprivate entities or associations that take on quasigovernmental functions, a network of relationships that is decisive in cultural activity abroad.

One of the ways of linking State and social organizations in this governance model was the ongoing support of the Catalan government in various social organizations, based in Catalonia, performing cultural actions abroad. For example, the establishment of the COPEC saw the creation of aid for "Grants to organizations for promoting Catalan culture abroad." This concept was established to support various associations and foundations. While in 1995 this line of action accounted for only 2\% of the total COPEC expenditure, which was of 318 million pesetas (COPEC, 1997, p.14), these subsidies were to remain active throughout the decade. The table below (Table 1) shows the trends in these subsidies between 1995 and 2001: 
Table 1. Number of COPEC grants to organizations for promoting Catalan culture abroad (million pesetas)

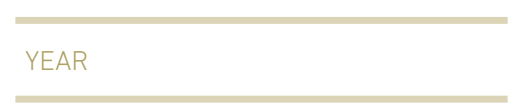

Cercle d'Agermanament Occità-Català

Fundació Congrés de Cultura Catalana

Institut d'Estudis Catalans

Institut de Projecció Exterior de la

Cultura Catalana

\begin{tabular}{cc}
$\frac{1995}{1}$ & \\
\hline 2 & \\
\hline 2 & \\
\hline 2 & \\
\hline
\end{tabular}

One of the associations in the table above is the l'Institut de Projecció Exterior de la Cultura Catalana (Institute for the dissemination of Catalan Culture abroad, IPECC). This association was set up in 1979. It derived from the congress on Catalan culture (Congrés de Cultura Catalana) held two years before and represented a backlash to the cultural repression wielded under Franco. This is an entity linked to nationalist militancy through cultural activities abroad. Its goals are "to disseminate knowledge about the Països Catalans (Catalan Countries) worldwide and spread the language, culture, history, traditions, etc., and the Catalan nationhood in all its manifestations." (IPECC, 2012). To do so, it established several lines of action, such as awarding the Premi Batista $i$ Roca for works projecting Catalan culture, such as symposia, meetings and seminars about the history and culture of Catalonia worldwide and Europe in particular. In many cases, these actions are undertaken by followers of the Catalan culture in different parts of the world or in co-operation with broadcasters. Many of the founding members of the IPECC are intellectuals and/or work in areas related to Catalan culture, such as historians, poets and writers.

As of the eighties, this institution received support from the Generalitat de Catalunya (Government of Catalonia). For instance, it undertook a task to place monuments commemorating Catalan artists, intellectuals or historians abroad, which involved the co-operation of the Catalan Government. As pointed out by its director Nuria Bayó, the former President Jordi Pujol accompanied IPECC in some of these actions: "We have placed three statues, always with

\begin{tabular}{c}
\hline 1997 \\
\hline 0.8 \\
\hline 1.5 \\
\hline 2 \\
\hline 1.2 \\
\hline
\end{tabular}

\begin{tabular}{c}
\hline 1998 \\
\hline 0.8 \\
\hline 1.5 \\
\hline 2.1 \\
\hline 1.2 \\
\hline
\end{tabular}
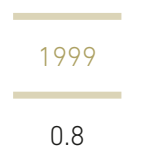

1.5
--

1.2

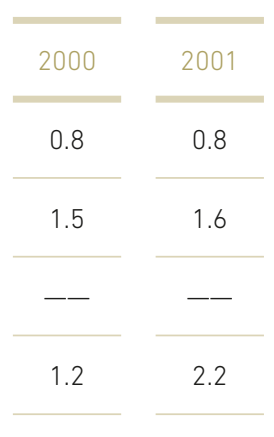

SOURCE: COPEC REPORTS 1995-2001. the economic support of the Catalan Government, and our President, Jordi Pujol, went to unveil a bust of our poet Josep Carner at the Catholic University of Brussels" (Bayó 2014, personal interview, $5^{\text {th }}$ March).

The pro-independent nature of the IPECC is reflected in the cultural activities carried out, among which we find its actions in different parts of Europe. The report on a trip to Krakow (Memòria de viatge a Cracòvia, 2010) provides details of the program planned for the occasion. The document questions the dearth of emphasis placed on nationalist issues by some of the events in the program, and the lack of respect for traditions. On this subject it states: "The dissemination of Catalonia's desire for independence should be present in events abroad. This was the case of Catalan musicians like Pau Casals, singers like Lluís Llach or athletes like Carles Puyol, etc. If the government does not do it, then at least we should do it ourselves." (IPECC, 2010, 3).

The emergence of the IRL involved the creation of a "counterpart" organisation at the official level. Since then, the IPECC had maintained a constant relationship with the IRL, for example by supporting the IRL in awarding the Premi Josep Maria Batista $i$ Roca. For its part, in 2003, the IRL founded the Premi Internacional Ramon Llull, through an agreement signed with the Fundació Congrés de Cultura Catalana, another of the entities in the table above. Thus, the roles previously "delegated" to the associations were "redistributed" and reconceptualised. Hereupon, with the progression of the economic crisis that began in 
2008 , the organization stopped receiving public funds and had to be maintained on the basis of private cooperation and some aid granted by the IRL. Regarding this new relationship with the Catalan government, its current director states:

"In fact we still exist, but nowadays the Generalitat undertakes foreign policy. Nonetheless, we are still needed. Because, when the new Generalitat was created (in the eighties), they celebrated the events that we still celebrate, such as the Batalla del Coll de Panissars (Battle of the Panissars pass). This great battle was won by our Rei Pere el Gran (King Peter III of Aragon). On winning this battle, he avenged the death of his grandfather in Muret, and this event should be celebrated. They celebrated it for the first few years, but then political party members, from the opposition, started attending and shouting insults. Now they have stopped attending all these activities still held by the IPECC. And they do not go, but they should keep the memory of Catalonia alive. But whoever comes with us will know all about this battle." (Bayó 2014, personal interview, $5^{\text {th }}$ March).

The Catalan PEN is another reference institution for cultural activity outside Catalonia. The international network of PEN clubs was established in 1921, when there was the foundation of PEN International in England. It emerged in the postwar period as an association of writers within the context of the creation of the League of Nations and the establishment of cultural diplomacy as an instrument of international dialogue. Then, the PEN in England invited writers worldwide to join this initiative. A year later witnessed the foundation of the PEN club of Catalonia, in Barcelona, which was the third in the world. It was brought into being by writers and intellectuals such as Josep M. LópezPicó, Joan Crexells or Josep M. Batista i Roca and, ever since, the institution has participated in PEN International meetings.
After its activism during Franco's dictatorship and the return of its leaders from exile, the Catalan PEN was reconfigured and resumed its relationship with the Catalan government. Ever since then, it has been funded by the Catalan Government and by several other state agencies. It has also been closely involved with the Catalan administration in organizing various activities and some of its members have formed part of government institutions. This relationship has been based on the ideology of the institution, which has always held a philosophy aimed at the link between civil liberties and human rights, and to promote the international dissemination and defence of the Catalan language, but also paying attention to the issue of national identity (Subirana, 2010).

Since 2001, as President of the Catalan PEN, Dolors Oller has sought to reconsider its way of working and bring it closer to the approach of its counterpart organizations in the Nordic countries and in England and North America. To this end, besides running tasks related to the Catalan literary world, it also takes new lines of action related to cultural paradiplomacy (Arenas 2014, personal interview, $18^{\text {th }}$ March). Arenas holds that this modification, which coincides with the appearance of the IRL, took place in a context of social and political change:

"It coincides with a time when, perhaps, there is a drop in the number of volunteers. In other words, as a country, in terms of recovering our institutions, people tend to think "now we have proper institutions that are responsible for protecting our heritage," so we relax as a civil society. And perhaps there was a generation, i.e., the generation that is now in its forties, which did not see the need to join such organizations nor to take proactive actions for culture. Why? Because there are other potential ways of reaching foreign countries." (Arenas 2014, personal interview, 18 March).

From this new position, the Catalan PEN, advisory member of UNESCO and the UN, promoted various lines of action designed to strengthen Catalonia's 
position in these supranational spheres and, on several occasions, acted against the Spanish State in defence of linguistic rights in the region. In this respect, it publicly condemned the state of committing "cultural genocide" of the Catalan language, and formally presented the indictment to PEN International to be raised with the UN (Foguet, 2012).

This statement came as a reaction to numerous measures taken to recentralize cultural and educational matters, undertaken by the central Government ${ }^{8}$. The initiative refers to the anti-Franco resistance upheld by writers, editors and intellectuals who had led the institution in exile. For example, on several occasions Batista and Roca reported the persecution of Catalan culture to the UN and UNESCO, as shown in the text "Appeal to the UNESCO on behalf of Catalan culture" (1952) presented in Paris (Subirana, 2010, 320). Within this policy, the organization also joined the groups belonging to Diplocat. The desire expressed by the Catalan intellectuals founders of the Catalan PEN, to represent a distinctive value of Catalan culture as a national culture (Subirana, 2011, 63), was now deployed within the framework of a new institutional project and in a different political context. The same was characterized by the international promotion of the right to choose by the government of Catalonia.

The UNESCO Centre of Catalonia (UNESCOCAT), in another supranational line of action integrated within this corporatist governance, was set up in 1984. One of the main missions of this NGO is to establish and strengthen ties between Catalonia and multilateral organizations ${ }^{9}$. According to its statutes, the association's mission is to "disseminate within the Catalan cultural ideals, documents and activities of UNESCO and made available to UNESCO co-operation of the Catalan cultural community in the areas of

8 Creating impediments for Catalan schooling in the Autonomous Communities of Valencia and the Balearic Islands, and to the reception of Catalan television in Valencia.

9 This centre was established on the basis of various UNESCO clubs and federations formed by civil society in Catalonia since the sixties (Mesado i Jardí, 2008, p.29) competence of UNESCO i.e., education, science, culture and communication." (UNESCOCAT, 2005, 5). The organization currently comprises four entities: Fundació Jaume Bofill, Institut d'Estudis Catalans (IEC), Fundació FemCAT and Òmnium Cultural.

Since its inception, the organization has been working with the Cultural Relations Service of the Catalan Ministry of Culture and received financial support from the Government of Catalonia, declared of public utility in 1996. In return, UNESCOCAT has worked under the umbrella of the Spanish Commission for Cooperation with UNESCO, providing information and technical advice to the Catalan Government.

Following this system of governance, UNESCOCAT officially maintained relations with UNESCO, in a consultative role. In 1993, the centre was admitted into this multilateral organization as a "Foundation having official ties with UNESCO," a condition renewed by the Executive Board in 1999 and 2008 for six-year terms. The activity of UNESCOCAT, as an association, enabled it to establish contacts in Paris with members of the multilateral organization, with state delegations and other NGOs worldwide, safeguarding the interest of Catalans. Furthermore, in 2001, the UNESCOCAT participated in organizing the Forum of Cultures, along with the city council and the Government of Catalonia (UNESCOCAT, 2001, 7). This line of action aimed at making proposals to UNESCO and incorporating its policies to regional programs, has increased continuously since the nineties. Thus, the activity of the NGO, focused on defending linguistic diversity, human rights and equity at work, became an "extension" of central and regional foreign policy, facilitating its ties with civil society.

Even though its scope has varied over time, this mechanism of indirect participation in UNESCO has several limitations, given the regulatory and administrative framework of the state, and its ability to act in the supranational context. This circumstance led to several appeals for the modification of Catalan representation mechanisms in the organization of States. For example, in 2001 various Catalan parties 
asked the Spanish government for greater official presence of Catalonia in UNESCO, but did not receive any response to the appeal (UNESCOCAT, 2001, 9). Accordingly, the two tripartite governments pursued different policies that sought to increase the capacity of Catalan governance in UNESCO. As part of this commitment, embodied in the 2006 Statute of Autonomy, and the promotion of policies linked to the organisation's programs, brought the relationship between UNESCOCAT and IRL closer (Institut Ramon Llull 2005, 84) and, in this context, in 2007 the UN reclassified this association as an organisation with "a special consultative status".

Despite progress in this governance model of Catalan representation in UNESCO, different actors in the Catalan cultural-political field emphasized the issues linked to its institutional ambiguity and the aforementioned "paradox" of Catalan cultural paradiplomacy connected with the lack of state structures. Baltà, Interarts consultant, pointed out two special characteristics of the Catalan cultural paradiplomacy environment, on the one hand, its sub-state nature and, on the other, the existence of a distinctive language and culture of international relevance:

"But precisely this mix of special characteristics, some positive and others negative, also magnifies the importance of the role of the civil society. The role which UNESCOCAT had taken on, in its time, for example regarding UNESCO, was beneficial even though it was a strange formula as it continued to be an NGO representing, or wishing to represent, Catalonia. Furthermore, UNESCO is within a context that does not facilitate the recognition of an entity unless it is a state. Therefore, when one is willing to participate, one can make some progress, but there are also certain limits." (Baltà 2013, personal interview, 18 ${ }^{\text {th }}$ September).

The tensions represented by this model of governance in relation to AGE and its aforementioned refutations at the autonomic level were partially solved by the agreement signed in 2013 between the Catalan Government and the Directorate of UNESCO. Likewise, it extends the powers of the Catalan Government in this organization and facilitates the placement of its own representatives, who act in parallel to the Spanish delegation. This process transpired one year after UNESCOCAT closed (2012) due to the drastic reduction in financial support from the Catalan Government, which is reflected in a reshaping of the relationship between civil society and the Catalan government in cultural action abroad.

Lastly, we should mention the Federació d'Organitzacions Catalanes Internacionalment Reconegudes (Federation of Internationally Recognized Catalan Organizations, FOCIR), an organization that includes many of the abovementioned organizations. It was created in 1995 aiming to "strengthen their presence in the area of international NGOs as well as promoting the NGOs that had not yet developed this facet of work." (FOCIR, 2010, 7). The FOCIR has been funded by the Catalan government and these resources were distributed among Federation members towards covering the costs of travel, logistics, training or promotion for over a decade. The Federation established consultancy services to advise those associations acting in international organizations and international networks of civil society, so they could do so as Catalans, thereby covering the lack of state structures enabling them to mediate in the international system (FOCIR, 2010, 7).

This focus emphasizes the importance of the transnational action of social organizations in structuring the new global governance. This framework legitimises governmental promotion of the internationalization of social actors in Catalonia. Nonetheless, at the Conference VIII Jornades de la FOCIR (2008), FOCIR Director, Mònica Sabata, stated: “We must be aware, however, that public diplomacy cannot substitute the tasks undertaken by governments and institutions" (FOCIR, 2008). She went on to explain the support of this union between civil society and the Catalan Government in foreign affairs: 
"We are a country that has not had the "normal", between quotes, structures of State in foreign issues, because we still lack full competence for international relations. But Catalan society is wise and has always looked towards Europe. Probably thanks to the legacy of President Pujol, who - when we were kids - told us we all had to look to the north, to Europe, and that Europe would be our answer. Some generations have grown up aware of this idea." (Sabata, 2014 personal interview, $4^{\text {th }}$ March).

Several cultural institutions are gathered together within FOCIR, becoming an instrument for promoting public cultural paradiplomacy. But since 2007, the coordination mechanisms between the government and the Federation have been transformed due to the revival of Catalan foreign policy and the creation of the Secretaria d'Afers Exteriors (Secretary for Foreign Affairs, SAE). Then the premises of the Secretaria de la Generalitat (Catalan Governmental Secretariat) began to take over some of its duties. Likewise, in the context of the economic crisis, FOCIR stopped receiving public funds, which it had spent on fostering the work of the associations at an international level and also decreased public aid for the operation of the organization. For these reasons, the structure and functions of FOCIR have changed in recent years, with it becoming a public diplomacy think tank working in collaboration with Diplocat ${ }^{\mathbf{1 0}}$.

\section{CONCLUSIONS}

For Keating $(1996,189)$, from the outset, Catalonia's action abroad constituted a way of affirming national identity, as a policy aimed at promoting economic

10 El Consell de Diplomàcia Pública de Catalunya (DIPLOCAT), derived from the Patronat Catalunya Món (World Board of Catalonia), is a consortium created in 2013 by the Government of Catalonia to project Catalonia in the international arena, aiming to show their project as favouring the right to decide. It is composed of several Catalan municipalities, provincial governments, universities and associations. development and also as a mechanism to protect Catalan culture. In this respect, also noteworthy is the importance of such cultural action abroad in nation-building processes, undertaken by various state and sub-state political bodies (Lecours and Moreno, 2003, Delgado Gómez-Escalonilla, 1991). Furthermore, this policy is a highly effective instrument for the reaffirmation of national territorial ideals, a rhetoric abroad that fosters the structuring of consensus in the international system. Moreover, within the context of sub-state entities, the political and cultural nature of language as well as its importance to identity, have given rise to various processes of social organization aimed at projecting local reality. In this respect, this article demonstrates the ability of nationalist social mobilization to serve as a tool for building governance, facilitating the organization of an autonomic sub-state cultural action.

The corporatist framework of governance of cultural paradiplomacy, analysed here, has been shaped by different alliances between the Catalan Government and industrial associations. These were based on the integration of numerous Catalan claims to government action abroad, mainly seeking to amend the limitations of this sub-state government in the field of supranational action. The strengthening of this co-operation in the nineties through the creation of governance led to a growing coercive interdependence among organizations belonging to this structure. Then the COPEC regrouped and institutionalized the mechanisms of public-private-associative relations while decreasing the dependence of autonomic paradiplomacy with respect to central Government.

The establishment of this corporatist governance in cultural paradiplomacy was promoted by: a) the gradual decentralization of responsibilities for, and administration of foreign affairs in Spain, mainly due to b) the existence of an organized social base dating from the democratic transition in terms of dissemination of culture in the national context; c) the government's willingness to establish a collaborative plan supported by these forces and their support. Given the importance of this relations framework on home policies and supranational activity 
in Catalonia, it was devised within a strategic action of Catalan cultural paradiplomacy and grew to become an important network of actors in the context of broader governance of Catalan cultural paradiplomacy, a meeting point of international promotion of the arts, cultural industry and heritage in different contexts.

This network of cultural paradiplomacy boosted the capacity for international action of the Catalan government, while also having an important instructive internal impact (Mellisen 2005) and enabled the diversification of its areas of political action. However, it also caused a series of tensions at each stage of Government, due to changes in the role of the Catalan Government in foreign policy and complex definition of common strategies between the government and social organizations. In this respect, governance was reshaped to create a new institutional framework as of 2000, and the new role assumed by the Institut Ramon Llull, an agency with more resources than COPEC, its predecessor. Since then it has been reorganized and rebalanced around the projection of Catalan language and culture within a national context.

While the nationalist dispute within the framework of various cultural paradiplomacy initiatives involved some confrontation between administrative strategies and mechanisms with respect to the central Government, at the regional level it was presented as a social "binder", a quality of the nationalism described by Bruilly (1990). Thus, as indicated by Anderson, promoting national awareness has the potential for socio-political mobilization and the building of sovereign power. As the same author (Anderson 1993, 284) states, heritage and historically accumulated documents help in the construction of a national narrative. The organization of an own foreign cultural policy in itself represents a formal aspiration to be a State, with the convergence of governmental agencies and private and associated actors in a complex bottom up / top down dialectic. Moreover, this policy established an official vision, based on the republican tradition and which portrayed the nation abroad as a distinct entity and (proto) sovereign.

\section{BIBLIOGRAPHIC REFERENCES}

Anderson, B. (2005). Comunitats Imaginades. València: Afers.

Arndt, R. T. (2009). ¿Cultura o propaganda? Reflexiones sobre medio siglo de diplomacia cultural en Estados Unidos. In Villanueva Rivas, C. (Ed.), Diplomacia pública y cultural (pp. 29-54). Mexico: Revista Mexicana de Política Exterior.

Arndt, R. T. (2005). The first resort of kings: American cultural diplomacy in the twentieth century. Dulles: Brassey's. Bélanger, L. (1994). La diplomatie culturelle des provinces canadiennes. Études internationales, 25(3), 421-452.

Bélanger, L. (1997). Les enjeux actuels de la participation du Québec à la francophonie multilatérale: de la paradiplomatie à la protodiplomatie. Politique et Sociétés, 16(1), 39-59.

Bouzada, X. (2007). La gouvernance de la culture en Espagne. In L. Bonet and E. Négrier (eds.), La politique culturelle en Espagne. París: Karthala.

Breuilly, J. (1990). Nacionalismo y Estado. Barcelona: Pomares-Corredor.

COPEC (1997). Memòria d'Activitats 1995, 1996, 1997. Barcelona: Departament de Cultura. Generalitat de Catalunya.

Cummings, M. C. Jr. (2003). Cultural Diplomacy and the United States Government: A Survey. Washington: Center for Arts and Culture.

Delgado Gómez-Escalonilla, L. (1991). Acción cultural y política exterior: la configuración de la diplomacia cultural durante el régimen franquista (1936-1945). (Tesis doctoral). Facultad de Geografía e Historia. Universidad Complutense de Madrid, Madrid.

Delgado Gómez-Escalonilla, L. and Figueroa, M. (2008). Los compromisos internacionales de España en materia de cultura. Documentos de Trabajo. Real Instituto Elcano de Estudios Internacionales y Estratégicos, 4, 1-21.

Departament de Cultura (1983). Memòria d'Activitats. Barcelona: Generalitat de Catalunya. 
Duchacek, I. D. (1990). Perforated sovereignties: toward a typology of new actors in international relations. In Soldatos, P. and Michelmann, J (eds.), Federalism and International Relations: the Role of Subnational Units (pp. 1-34). New York: Oxford University Press.

FOCIR (2008). VIII Jornades de la FOCIR. Barcelona, Institut d'Estudis Catalans, 25 th October 2008.

FOCIR (2010). X Jornades de la FOCIR. La diplomàcia cultural al servei de la projecció internacional de Catalunya. Internacional.cat., 5. Barcelona: FOCIR, Generalitat de Catalunya.

Foguet, J. (2012). Mascarell quiere exportar la cultura catalana para sortear la crisis. El País, $21^{\text {st } J a n u a r y ~} 2012$.

García Segura, C. (1995). La dimensión mediterránea de la proyección exterior de Cataluña: el Arco Latino. Papers: Revista de sociologia, 46, 46-56.

Gasòliba, C. A. (1987). Cataluña y la Comunidad Europea. Catalònia cultura, 4, 48-49.

Gellner, E. (1997). Naciones y nacionalismo. Madrid: Alianza.

Higham, R. (2007). The World Needs More Canada. Canada Needs More Canada. In Baillargeon, J. P. (Ed.) The Handing Down of Culture: Smaller Societies and Globalization (pp. 134-142). Toronto: Grubstreet Books.

Hobsbawm, E. (1991). Naciones y nacionalismo desde 1780. Barcelona: Crítica.

Hroch, M. (1994). La construcción de la identidad nacional: del grupo étnico a la nación moderna. Revista de Occidente, 161, 45-60.

Institut Ramon Llull (2005). Memòria IRL 2004. Barcelona: Institut Ramon Llull.

IPECC (2012). Què és l’IPECC?. Tríptic informatiu (en línea). http: //ipecc.cat/novaweb/que-es-lipecc/, access 23/5/2014.

IPECC (2010). Memòria de viatge. Barcelona: IPECC.

Johannisson, J. (2010). Making Geography Matter in Cultural Policy Research: The Case of Regional Cultural Policy in Sweden. In Singh, J. P. (Ed.), International Cultural Policies and Power (pp. 127-139). New York: Palgrave Macmillan.

Keating, M. (1996). Naciones contra el Estado. El nacionalismo de Cataluña, Québec y Escocia. Barcelona: Ariel.

Kedourie, E. (1998). Nationalism. Massachusetts: Blackwell.

Lecours, A. and Moreno, L. (2003). Paradiplomacy and stateless nations: a reference to the Basque Country. Montreal: The Institute for Research on Public Policy.

Mark, S. (2008). A Comparative Study of the Cultural Diplomacy of Canada, New Zealand and India. (Tesis doctoral). Auckland: University of Auckland.

Mellisen, J. (Ed.), (2005). The New Public Diplomacy. London: Palgrave.

Mesado, À. (2008). Els ens subestatals i la UNESCO. Els casos de Catalunya i el Quebec. Barcelona: Generalitat de Catalunya.

Michelmann, H. (Ed.), (2010). Foreing Relations in Federal Countries. Montreal: McGill-Queen's University Press.

Paschalidis, G. (2009). Exporting national culture: histories of Cultural Institutes abroad. International Journal of Cultural Policy, 15(3), 275-289.

Peters, G. (1995). Modelos alternativos del proceso de la política pública. De abajo hacia arriba o de arriba hacia abajo. Gestión y Política Pública, 4(2), 257-276.

Peters, G. and Savoie D. J. (Eds.), (1995). Governance in a changing environment. Montreal: Canadian Centre for Management Development, Centre canadien de gestion, McGill-Queen's University Press.

Petit Bozzo, M. (2010). Fonaments i propostes per a una (para)diplomàcia de Catalunya a la UNESCO. Quaderns de Recerca, UNESCOCAT, 2, 1-45.

Rodríguez Morató, A. (Ed.) (2007). La sociedad de la cultura. Barcelona: Ariel.

Saul, J. R. (1994). Culture and Foreign Policy. In Canada's Foreign Policy: Position Papers. Report Of the Special Joint Committee of the Senate and the House of Commons reviewing Canadian Foreign Policy. Ottawa: Canadian Communication Group Publishing.

Schuster, J. M. (2002). Sub-national cultural policy - Where the action is: mapping state cultural policy in United States. International Journal of Cultura Policy, 8(2), 181-196.

Sharp, P. (1999). For diplomacy: Representation and the Study of International Relations. International Studies Review, 1(1), 33-57.

Subirana, J. (2010). Fem d'una mena d'ambaixadors...' La proyección internacional como estrategia de las literaturas 'menores'. El caso del PEN catalán. Oihenart. Cuadernos de Lengua y Literatura, 25, 307-324. 
Subirana, J. (2011). Organitzacions literàries i mediacions: el cas del PEN català. In Gavagnin, G. and Martínez-Gil, V. (Eds.), Entre literatures. Hegemonies i periferies en els processos de mediació literària (pp. 59-79). Lleida: Punctum.

UNESCOCAT (2006). Memòria 2005. Barcelona: UNESCOCAT.

Villalonga Vadell, A. (1992). Las relaciones institucionales entre la Comunidad Autónoma de Cataluña y América Latina. Revista CIDOB d'Afers Internacionals, 23, 323-328.

Villanueva, C. (2007). Representing Cultural Diplomacy: Soft Power, Cosmopolitan Constructivism and Nation Branding in Mexico and Sweden. Växjö: Växjö University Press.

Villarroya Planas, A. (2010). Política cultural. Cataluña. In Consejo de Europa/ERICarts (Ed.), Compendium of Cultural Policies and Trends in Europe. Barcelona: Generalitat de Catalunya.

Wiarda, H. J. (1996). Corporatism and Comparative Politics. New York: M. E. Sharpe.

Wyszomirski, M. J., Burgess, C. and Peila, C. (2003). International Cultural Relations: A Multi-Country Comparison. Ohio: Center for Arts and Culture.

\section{BIOGRAPHICAL NOTE}

Mariano Martín Zamorano was awarded a PhD in Cultural Management and Heritage by Universitat de Barcelona (UB), Cum Laude and with International Mention. He has wide experience in carrying out funded interdisciplinary academic projects - Universidad Nacional de Cuyo (UNC, Argentina), AECID and the European Commission — and has obtained four individual grants (from (UNC, AGAUR and UB). Since 2010, he has been a member of the UB's Centre for the Study of Culture, Politics and Society (CECUPS). Zamorano's publications include various papers in leading scientific journals, a book pending publication and a chapter in another book. 